\title{
A Study of the Mallomonas, Synura and Chrysosphaerella of Northern Iceland
}

\author{
BY D. E. BRADLEY \\ Department of Zoology, University of Edinburgh, Scotland
}

(Received 5 May 1964)

\begin{abstract}
SUMMARY
Species of the genera Mallomonas, Synura and Chrysosphaerella have been investigated in relatively few countries, and a study of their occurrence in Iceland provides additional information on their distribution. Several new species of Mallomonas ( $M$. calceolus, sp.nov.; $M$. pugio, sp.nov.; $M$. clavus, sp.nov., M. maculata, sp.nov.) and one of Chrysosphaerella (C. multispina sp.nov.) were found together with numerous species already described. In this paper, observations with both light and electron microscopes are given in detail for the new species. Electron micrographs of the scales and bristles of known species are also shown and, where appropriate, compared with those of the new ones. Three out of the four new species of Mallomonas fitted into the existing taxonomic groups, one belonging to the Tripartitae, one to the Planae and one to the Torquatae. The fourth was added to a group already containing three isolated species. The new Chrysosphaerella species is of particular interest because only a few species have so far been described in this genus.
\end{abstract}

\section{INTRODUCTION}

The three genera of the Chrysophyceae investigated tend to favour rather cold climates and have been studied by workers in Central Europe, England, Denmark, the Soviet Union, Japan and Alaska. Because of its climate, Iceland seemed likely to provide a particularly suitable habitat and to add to our knowledge of these organisms. For practical reasons it was not possible to study their distribution over a wide area; the region covered was in Northern Iceland around Akureyri. Some thirty-five ponds, pools and ditches were sampled and, while the occurrence of live organisms was relatively rare, identifiable scales and bristles were found in twentythree samples. The present paper discusses and describes the species found and how the new ones fit into the existing scheme of classification (Harris \& Bradley, 1960).

\section{METHODS}

Preliminary observations with the light microscope were made in the field. Samples (about $12 \mathrm{ml}$.) were collected from ponds, pools and ditches and centrifuged at about $1500 \mathrm{rev} . / \mathrm{min}$. for $15 \mathrm{~min}$. in a battery-driven centrifuge to concentrate organisms, which were resuspended in $0.2-0.5 \mathrm{ml}$. of water. A little of the suspension was transferred to a slide and examined with the light microscope. The remainder was dried down on slides for later examination in the electron microscope. In addition, organisms from each sample were disintegrated by placing a small 
crystal of chloral hydrate in the drop of suspension on the slide before drying. Thus, preparations containing whole and disintegrated organisms were available for electron microscopy.

Specimens were prepared for electron microscopy as follows. A layer of carbon about $200 \AA$ thick was deposited on the microscope slide with the organisms on it. This was then backed with a layer of Bedacryl $122 \mathrm{X}$ (made by I.C.I. Ltd.) by allowing a $5 \%$ solution of the plastic in benzene to flow over the slide, which was drained vertically and allowed to dry. Small circles were then scored in the combined film in the areas containing organisms. These portions were floated on to a water surface and picked up on support grids. The Bedacryl backing was finally washed away by immersing the grids in chloroform for $15 \mathrm{~min}$. This procedure transferred the organisms, scales and bristles from the microscope slides to the support grids. Replicas were obtained by floating the grids, carbon film uppermost, on dilute hydrofluoric acid for $15 \mathrm{~min}$. The replicas were subsequently shadowed with platinum or gold + palladium alloy.

Particular care was taken in appropriate cases (e.g. Mallomonas clavus) to ensure that scales figured from the electron microscope belonged to species drawn from the light microscope.

The $\mathrm{pH}$ values of the water samples were taken from the water itself rather than from the subsoil.

\section{MALLOMONAS}

The species of Mallomonas are grouped and described according to the classification and nomenclature proposed by Harris \& Bradley (1960).

\section{Series I. Tripartitae}

Mallomonas calceolus sp.nov. (Figs. 1, 2; Pl. 1, figs. 1-5)

Diagnosis. Cellula ovoides, post et ante rotundata. Setis contecta brevibus et gracilibus. Chromatophoros valde bilobata, viridis. Flagellum fere sesqui longius quam corpus. Squamae parvae, ovatae, tripartitae, unaquaque setam ferens. Fundus squamae paucis punctis et papillis conspicuis signatus. Setae breves, fere altero tanto longiores quam squamae, leves, bicipites.

Dimensiones. Cellula 11-18 $\mu \times 9-12 \mu$, squamae 3-4 $\mu \times 1-2 \mu$, setae anteriores circa $15 \mu$, setae corporis 4-6 $\mu$.

English diagnosis. Cell ovoid, rounded both ends. Covered all over with short slender bristles. Chromatophore strongly bilobed, green. Flagellum about one and one-half times body length. Scales small, oval, tripartite, with one bristle attached to each. Base plate of scale has a few puncta and well-marked papillae. Bristles short, about twice scale length, smooth but with divided tip.

Occurrence. Found under ice in mid-January 1962 in a flooded pasture at Leadburn, Midlothian, Scotland; Nat. Grid 237/562; the water, dung-contaminated, was at $\mathrm{pH} \mathrm{7.0.} \mathrm{The} \mathrm{localities} \mathrm{in} \mathrm{Iceland} \mathrm{(July} \mathrm{1963)} \mathrm{were} \mathrm{Kleif,} \mathrm{Arskogsströnd} \mathrm{(live}$ organisms); Hverhóll, Skidadalur and Mordruvellir provided scales and bristles only. These waters were also at $\mathrm{pH}$ 7·0. Mrs K. Harris (personal communication) found it at Highclere, Berkshire, England, in 1957 and 1962.

Name derivation. The name 'calceolus' refers to the slipper-like shape of the scales. 
Additional characters. Mallomonas calceolus is small and insignificant in the light microscope, the bristles of the living organism being barely discernible; the deeply bilobed chromatophore is clearly visible. When dried down on to a microscope slide, the organism readily disintegrates without the need to add chloral hydrate. The scales and bristles can be discerned (Fig. 2) provided the pond water is relatively free from soluble matter, which easily obscures them on drying; little structure can be seen on the scales other than a thickening at either end.
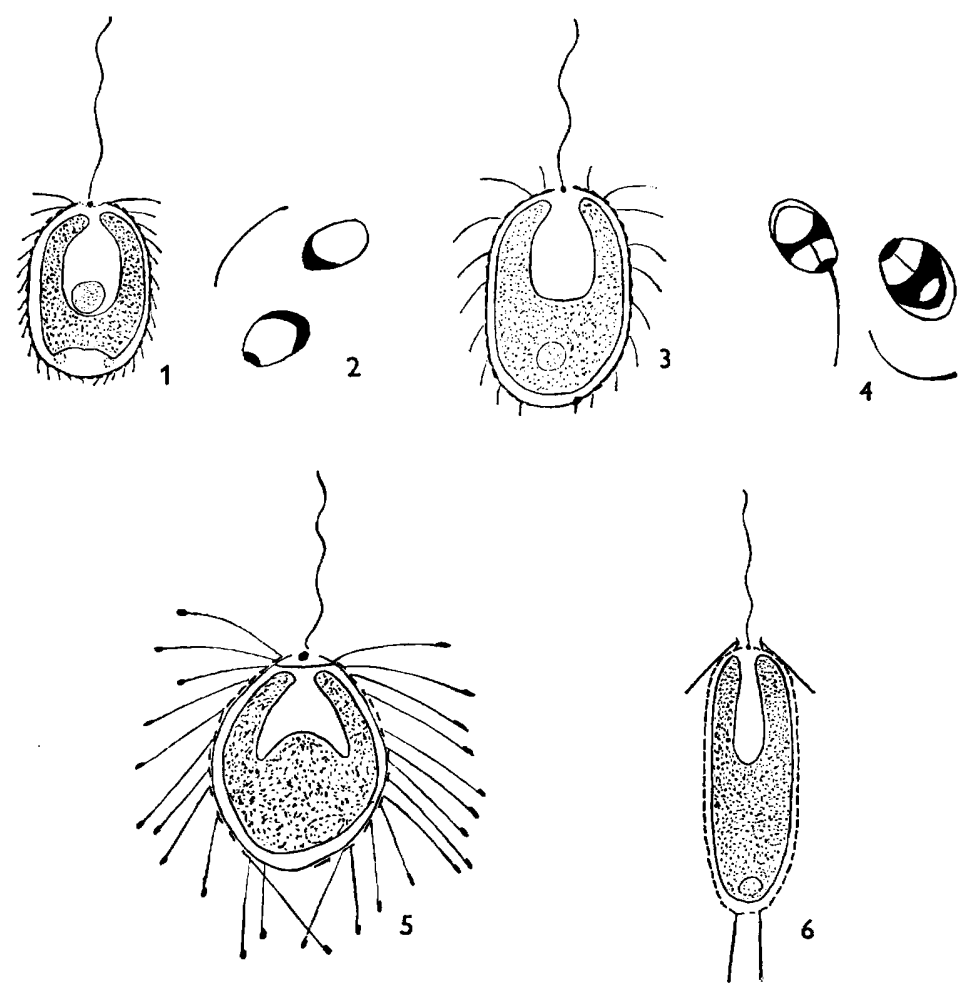

Fig. 1. Mallomonas calceolus, mature cell, $\times 1000$.

Fig. 2. M. calceolus, scales and bristles, $\times 2000$.

Fig. 3. M. pugio, mature cell, $\times 1000$.

Fig. 4. M. pugio, scales and bristles, $\times 2000$.

Fig. 5. M. heterospina, mature cell from Mordruvellir, $\times 1000$.

Fig. 6. M. clavus, mature cell, $\times 1000$.

Electron micrographs of shadowed and unshadowed scales and bristles clearly reveal their structure (Pl. 1, figs. 1-3). The shadowed replica of the underside of a scale in Pl. 1, fig. 4, shows that it is smooth except for a depression beneath the dome to which the bristle is attached. This species clearly belongs to the Papillosa group of the Tripartitae (Harris \& Bradley, 1960). A fully developed and an immature scale are shown in $\mathrm{Pl}$. 1, fig. 5 . 
Mallomonas acaroides Perty (Pl. 1, figs. 6, 7; Pl. 2, figs. 8-12, 15)

This species has been well studied in the electron microscope (Asmund, 1959; Harris \& Bradley, 1960) and no less than three varieties have been described. These are compared in both the above works, but the pertinent differences may be mentioned here. $M$. acaroides var. craquissima is the most easily distinguished; its scales are readily differentiated from the other two varieties in that they are heavier and well reticulated (Pl. 1, fig. 6). The differences between the other two, $M$. acaroides var. striatula and var. galeata are slight. Their scales are identical and much more delicate than those of $M$. acaroides var. craquissima (Pl. 1, fig. 7). However, $M$. acaroides var. striatula has two types of bristle, one with and one without a 'helmet' tip, this being shown in Pl. 1, fig. 7. M. acaroides var. galeata has only helmet bristles.

Mallomonas acaroides var. galeata appears to be common in Northern Iceland, and as a result it has been possible to carry out a study of bristle variation. In a population from Hverhóll, Skidadalur, bristles were found with variations in the shape of their helmet tips. None of the toothed bristles typical of $M$. acaroides var. striatula could be found so it was concluded that the variety present was 'galeata'. A series of electron micrographs illustrating the bristle tips is shown in Pl. 2, figs. 8-11. In Pl. 2, fig. 8, there is a simple pointed tip with some thinning. Plate 2, fig. 9 , shows a stage where the pointed tip has become more extended and sharper, and a widening of the shaft resembling the hood of a cobra has begun to appear just beneath it. The bristle in $\mathrm{Pl}$. 2, fig. 10, is much further advanced, the typical helmet shape beginning to form. It seems, however, that this is an abnormal tip since the lower portion of the helmet has developed in the wrong way. This can be seen clearly by comparing it with the fully formed tip in Pl. 1, fig. 7. Pl. 2, fig. 11, also appears to be abnormal, the top part of the helmet having developed incorrectly.

Mallomonas acaroides var. craquissima bristles were found in three localities, near Kleif, Másvatn, and Myvatn, the last being the most productive of live organisms. Two kinds of helmet bristle were found here (Pl. 2, figs. 12, 15) with and without serrations. No serrated bristles without helmets could be found.

The observations described here emphasize the variation in bristle structure which may be found in all varieties of Mallomonas acaroides. The varieties 'striatula' and 'galeata' rely upon bristle structure for their identification; the main criterion is that the former possesses serrated bristles without helmets, whereas the latter does not. These two varieties cannot therefore be identified from scales alone.

\section{Other species}

Mallomonas papillosa (Harris \& Bradley, 1957) was the third species of the Tripartitae identified. It was found in several localities: Kleif, Skidadalur and Svarfadadalur. The scales showed the characteristic wide variation in structure. Scales of $M$. papillosa forma annulata (Harris \& Bradley, 1960) were found near Akureyri. A few scales of $M$. striata var. serrata (Harris \& Bradley, 1960) were found at Másvatn (Pl. 2, fig. 16).

In addition, scales of two hitherto undescribed species belonging to the Tripartitae were found. The first, from Másvatn and Myvatn (Pl. 2, figs. 14, 17), has 
also been found near Reading, Berkshire, and will be described in detail in a future publication (Mrs K. Harris, personal communication). The honeycomb structure of the scale is an obvious characteristic which permits its quick identification in the electron microscope. The second species (Pl. 2, fig. 13) has not previously been figured. It is considered that the illustration of isolated scales of undescribed species is of value even if there are insufficient data for a full description; information is provided about the distribution of the species if it is subsequently described in detail.

\section{Series II. Planae}

Mallomonas pugio sp.nov. (Figs. 3, 4; Pl. 3, figs. 22-25)

Diagnosis. Cellula ovoides vel paene rotundata. Chromatophoros profunde lobata. Flagellum fere duabus tertiis partibus longius quam corpus. Cellula setis brevibus, subtilibus, paullo arcuatis contecta. Squamae ovatae et subtiles, cupola satis magna et costata, proprie reticulatae ut ex costis prominentibus compositae. Pars distalis vulgo in duas, aliquando in tres regiones divisa. In cupola costae septum vel octo, axi longo squamae parallelae. Setae breves, acutissimae, uno parvo dente aptatae.

Dimensiones. Cellula 12-20 $\mu \times 10-15 \mu$, squamae 4-6 $\mu \times 2 \cdot 5-3.5 \mu$, setae 5-6 $\mu$.

English diagnosis. Cell ovoid to nearly spherical. Chromatophore deeply lobed. Flagellum about two-thirds body length. Cell covered with short, slightly curved, delicate bristles. Scales oval and delicate with fairly large ribbed dome and characteristic reticulation, consisting of raised ribs. The distal portion is usually divided into two, sometimes three areas. Ribs on dome seven or eight, parallel to the long axis of the scale. Bristles short, very sharply pointed with single small tooth.

Occurrence. Found only at Hverhóll, Skidadalur, near Dalvik, Iceland, in July 1963. It was well distributed in several stagnant pools ( $\mathrm{pH} 7 \cdot 0-7 \cdot 2)$ over a large area of a valley floor.

Name derivation. The name 'pugio', meaning dagger, refers to the form of the bristles.

Additional characters. Mallomonas pugio appears in the light microscope as a delicate organism slightly larger than $\boldsymbol{M}$. calceolus, the bristles being clearly visible (Fig. 3). It readily disintegrates on drying and the scales show their easily recognizable characteristic markings and the dome which appears as a thickened patch at the distal end (Fig. 4).

The appearance of the scales and bristles in the electron microscope is quite distinctive (Pl. 3, figs. 22-25). Some scales show variations such as the form of the ribs on the dome (Pl. 3, fig. 22). A very few are in the form of flat reticulated oval discs (Pl. 3, fig. 23). It is not known to which part of the cell these scales belong. One scale in Pl. 3, fig. 24, appears to have two bristles; it is believed that the second one has drifted into this position during drying and that the live organism has only one bristle per scale.

Mallomonas heterospina Lund (1942) (Fig. 5; Pl. 2, fig. 18; Pl. 3, figs. 19-21).

This was the only other species of the Planae series to be found, the locations being at Kleif, Skidadalur (Hverhóll) and Mordruvellir. The live organisms from Mordruvellir (Fig. 5) showed the spanner-like hooked bristles well in the light microscope and there was no difficulty about recognizing the species. Both hooked and 
straight bristles were found at Kleif (Pl. 3, figs. 19, 21), but only hooked bristles at Skidadalur and Mordruvellir (Pl. 3, fig. 20).

Comparison of Mallomonas pugio, Mallomonas heterospina, and Mallomonas multiunca. The first species described in this group was Mallomonas heterospina Lund (1942), who used only the light microscope. The hooked and straight bristles were visible. M. multiunca was described by Asmund (1956) and compared to $M$. heterospina with both light and electron microscopes. Harris \& Bradley (1957, 1960) also compared the two species, and, while they resemble one another in some characteristics such as having hooked bristles and having rather similar scales, it seems that $\boldsymbol{M}$. heterospina and $\boldsymbol{M}$. multiunca are taxonomically distinct. $M$. pugio has scales which are superficially similar to both the above species in some respects. The three species clearly form a group and the main features of interest are given in Table 1. The fine structure of the scales is quite characteristic for each species, and that of $M$. pugio may even be clearly recognized in the light microscope. The live organism of $M$. pugio is not distinctive in the light microscope, unlike the other two species, because of its lack of hooked bristles. It could only be confused with $M$. heterospina and $\boldsymbol{M}$. multiunca when these are juvenile, in which condition they possess no hooked bristles. No hooked bristles were found in any population of M. pugio.

Table 1. Features of Mallomonas heterospina, M. multiunca and $M$. pugio

\begin{tabular}{llll} 
Scales & \multicolumn{1}{c}{ M. heterospina } & \multicolumn{1}{c}{ M. multiunca } & \multicolumn{1}{c}{ M. pugio } \\
Bristles & Smooth dome & Ribbed dome & Ribbed dome \\
& $\begin{array}{l}\text { Straight and hooked, } \\
\text { hooked with no fine } \\
\text { point }\end{array}$ & $\begin{array}{c}\text { Straight and hooked, } \\
\text { hooked has fine point }\end{array}$ & Straight only \\
& &
\end{tabular}

The two better-known species appear to occur widely. Mallomonas heterospina has been recorded from Richmond Park (Lund, 1942), Berkshire (Harris \& Bradley, 1957) and Denmark (Asmund, 1956), and in the present paper from Iceland. Mallomonas multiunca was recorded in Denmark and Berkshire by the same authors and has been found in Edinburgh, Scotland, by Bradley, but not at all in Iceland. M. pugio was only found in the type locality in Iceland and in none of the surrounding areas. The three species all seem to favour winter/spring conditions, except $\boldsymbol{M}$. multiunca, which has also been recorded (at its type locality) in early autumn.

\section{Series IV. Torquatae}

Mallomonas clavus sp.nov. (Fig. 6; P1. 4, figs. 30, 31, 34--36)

Diagnosis. Cellula ovoides, ante longa et tenuis, collari aptata squamarum quattuor vel quinque prominentium et setas ferentium. Post rotundata sed fere quattuor longis cuspidibus armata. Chromatophoros viridis, $\mathrm{H}$-formis. Flagellum dimidio brevius quam corpus. Squamae collaris asymmetricales, cupola levi et apice acuto. Squamae corporis rhomboides. Squamae omnes margine prominenti. Regio interior poris ordinate dispositis et reticulationibus prominentibus insignis. Setae anteriores simplices. Squamae posteriores in cuspides longas et tenues elongatae.

Dimensiones. Cellula 20-30 $\mu \times 6-9 \mu$, squamae corporis 3.5 $\mu \times 2.5 \mu$, squamae collaris $4.5 \mu \times 2 \mu$, setae $7 \mu$, clavi $2-10 \mu$. 
English diagnosis. Cell ovoid, long and thin, anterior end with collar of four to five forward-pointing scales with bristles, posterior end rounded but with about four long spikes. Chromatophore green, $\mathrm{H}$-shaped. Flagellum about one-half body length. Collar scales asymmetric, with smooth dome having a sharp point. Body scales rhomboidal. All scales have raised margin, inner region regularly perforated also with raised reticulations. Anterior bristles simple, posterior scales elongated into long spikes.

Occurrence. Found only at Hverhóll, Skidadalur, near Dalvik, Northern Iceland, in deep pit in mountain valley in July 1963, in water at $\mathrm{pH} 7 \cdot 0$.

Name derivation. The name 'clavus', Latin for spike or nail, refers to the posterior spikes which characterize the species.

Comparison. Mallomonas clavus has features in common with $\boldsymbol{M}$. doignonii Bourelly (1951), M. lefeuvrei Villeret (1954), M. pumilio Harris \& Bradley (1957), M. pumilio var. silvicola Harris \& Bradley (1960) and $M$. eoa Takahashi (1963). In the light microscope it might easily be confused with $M$. doignonii, $M$. lefeuvrei or $M$. eoa, the species being similar in appearance with long posterior spikes and anterior bristles. Thus, to effect a proper identification, the electron microscope is required to show up the differences in scale structure. The cell of $M$. doignonii is the same size as that of $M$. clavus, but the scales have transverse ribs parallel to their short axis while $\boldsymbol{M}$. clavus has perforations and reticulations. A comparison with unpublished electron micrographs of $M$. lefeuvrei (Mrs K. Harris, in preparation) shows that the scales and rear spines of this species are much thicker than those of $M$. clavus. The scales of $M$. eoa are also thicker than those of $M$. clavus and are ornamented with round pores instead of reticulations. In fact, the scale structure of $M$. clavus is identical with that of $\boldsymbol{M}$. pumilio so that it might be confused with this species if isolated scales only were found in the electron microscope. In the light microscope, however, $M$. pumilio is much smaller and lacks the long posterior spikes, though it sometimes has very short ones. $M$. pumilio var. silvicola shows a somewhat closer resemblance in the light microscope, but again lacks the long spikes. In the electron microscope the scales have a different ornamentation.

There has been a good deal of confusion in the past concerning the identification of species in the Torquatae, a matter discussed by Harris \& Bradley (1960). Since $M$. clavus seems virtually indistinguishable from several other species in the light microscope, it is impossible to say to which species past observations with this instrument refer. This group is obviously so confusing that a careful detailed study with both light and electron microscopes on existing and additional material is needed to clarify its taxonomy.

Undescribed species (Pl. 4, figs. 27-29)

Numerous loose scales of undescribed species belonging to the Torquatae were found in the electron microscope in water from Hverhóll, Skidadalur. Their appearance is close to that of Mallomonas phasma Harris \& Bradley (1960) and $M$. mangofera Harris \& Bradley (1960), but distinguishable by a ribbed structure round the distal edge. The anterior collar scales have a small pointed fin (PI. 4, fig. 27) like $\boldsymbol{M}$. pumilio and $\boldsymbol{M}$. clavus, while the body scales are rhomboidal (Pl. 4, fig. 28). 


\section{ISOLATED SPECIES}

Mallomonas maculata sp.nov. (Pl. 3, fig. 26; Pl. 5, figs. 37-41)

Diagnosis. Cellula oblonga. Ante prope cuspidata, squamis tribus vel quattuor setas ferentibus breviores, leves, paullo arcuatas. Ante squamae elongatae et oblique flexae. Squamae omnes sine cupola et crassiores, intus papillosae. Superficies magna parte levis sed papillis paucis et sine ordine sparsis signata. Labium prominens et conspicuum circa latus proximale squamae. Circa partem interiorem labii foveae circulatim dispositae. Post squamae paullo elongatae. Post et ante squamae foveam ferunt magnam sed brevum in medio et in uno latere.

Dimensiones. Cellula circa $15 \mu \times 30 \mu$, squamae 3.5-4.5 $\mu \times 2-3 \mu$, setae 8-10 $\mu$.

English diagnosis. Cell oblong. Anterior end more or less pointed with three or four scales bearing rather short smooth slightly curved bristles. Anterior scales elongated and curved to one side. All scales domeless and rather thick with internal papillose structure; surface generally smooth but with a few papillae irregularly distributed; a marked raised rim present round the proximal edge of the scale with a ring of pits round the inside of the rim. Posterior scales slightly elongated. Anterior and posterior scales have a large shallow pit in centre and on one edge.

Occurrence. Found only in a small man-made pit containing water at $\mathrm{pH} 7 \cdot 0$ at Kleif, Arskogsströnd, near Akureyri, in July 1968. Only one dried individual was found, but it was possibly to study this organism in detail in the electron microscope.

Name derivation. The name 'maculata', meaning spotted, refers to the appearance of the scales in the electron microscope.

Comparison. The scales of Mallomonas maculata to some extent resemble those of both M. akrokomos Pascher and M. adamas Harris \& Bradley (1960). While the presence of large pits is a characteristic of the Quadratae group, to which the latter species belongs, other structural features such as the shape of the anterior and posterior scales are not; the species has thus been placed in the group of isolated species. The main diagnostic feature of the organism is the internal papillose structure. The fact that the spotting on the scales is internal can be deduced from their relatively smooth appearance when examined as replicas (Pl. 5, figs. 39-41). Direct electron micrographs of scales (PI. 5, figs. 37, 38) show the dense array of spots.

\section{Mallomonas akrokomos Pascher (Pl. 4, fig. 33)}

A very sparse population of this species was found at Mordruvellir and scales were found at Myvatn. The species was well studied in the electron microscope by Harris (1958); no additional information has been obtained in the present work, the organism being typical in both light and electron microscopes.

\section{SYNURA}

Three species of the genus Synura were found in northern Iceland, two of them, S. petersenii Korshikov (Pl. 5, fig. 43) and S. echinulata Korsch. (Pl. 5, fig. 42) being common and numerous. Live organisms or scales were present in samples from almost all localities. One of the scales in Pl. 5, fig. 42, is probably in the process of developing, since it is thinner and more delicate than the other.

The third species, Synura spinosa Korsch., was detected by the presence of a very 
small number of scales from Mordruvellir and Akureyri. One of these from near Akureyri (Pl. 4, fig. 32) can be identified as $S$. spinosa forma spinosa Petersen \& Hansen (1956), by the presence of two teeth on the tip of the spine. No new information was obtained about these species.

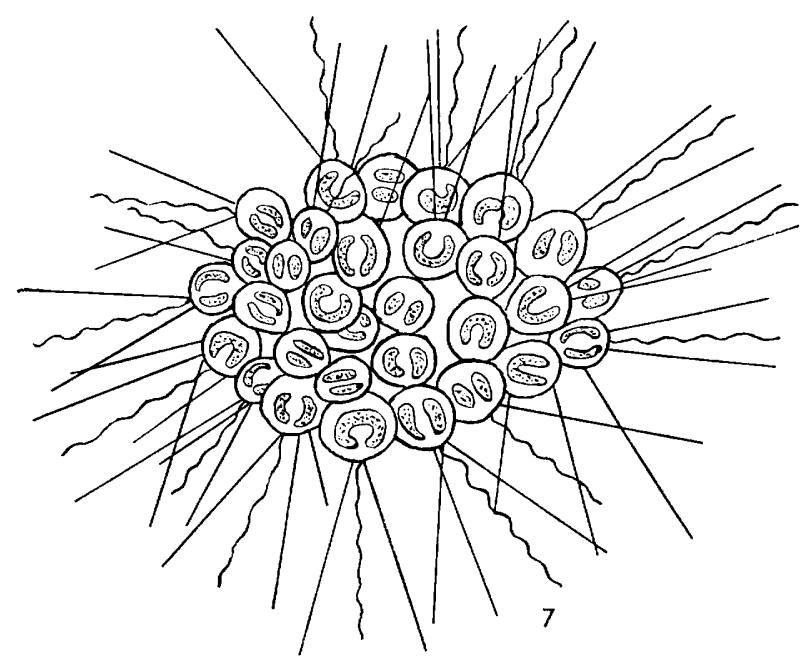

Fig. 7. Chrysosphaerella multispina, living colony, $\times 500$.

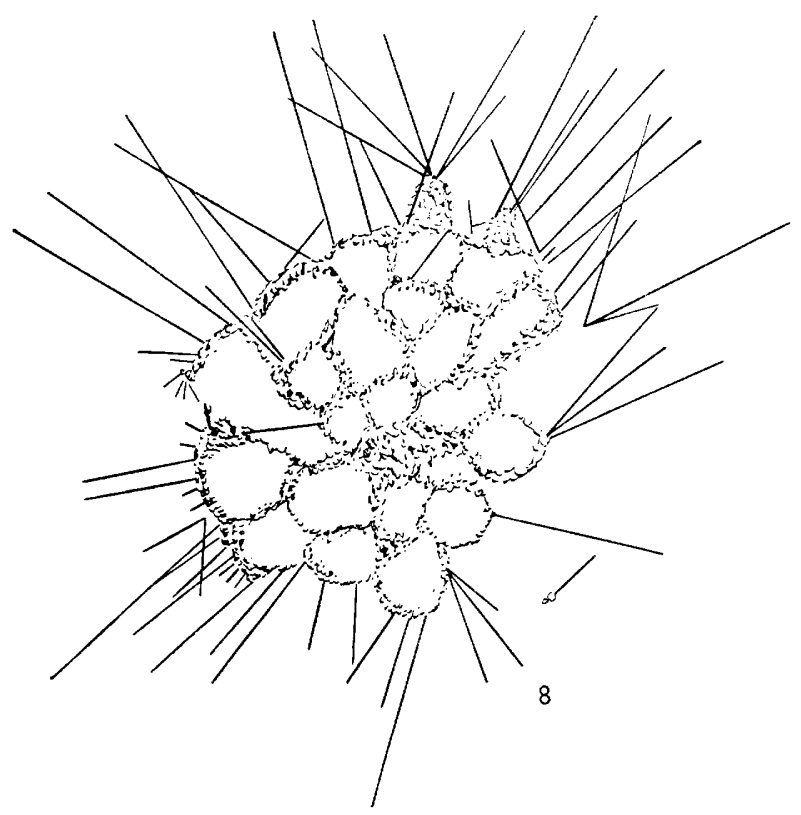

Fig. 8. C. multispina, dried colony, $\times 500$. 


\section{CHRYSOPHAERELLA}

The large colonial organisms of the genus Chrysophaerella Lauterborn (1896) with their numerous spines are easy to find with the light microscope. Differentiation of the species is, however, a difficult matter and can only really be achieved with an electron microscope. The taxonomy of the genus was discussed in detail by Harris \& Bradley (1960). Only a few species have been described so far: C. longispina Lauterborn (1896, 1899), C. brevispina Korshikov (1941), and a third species, C. rhodei Skuja (1948), which Harris \& Bradley (1960) believed to be identical with C. brevispina.

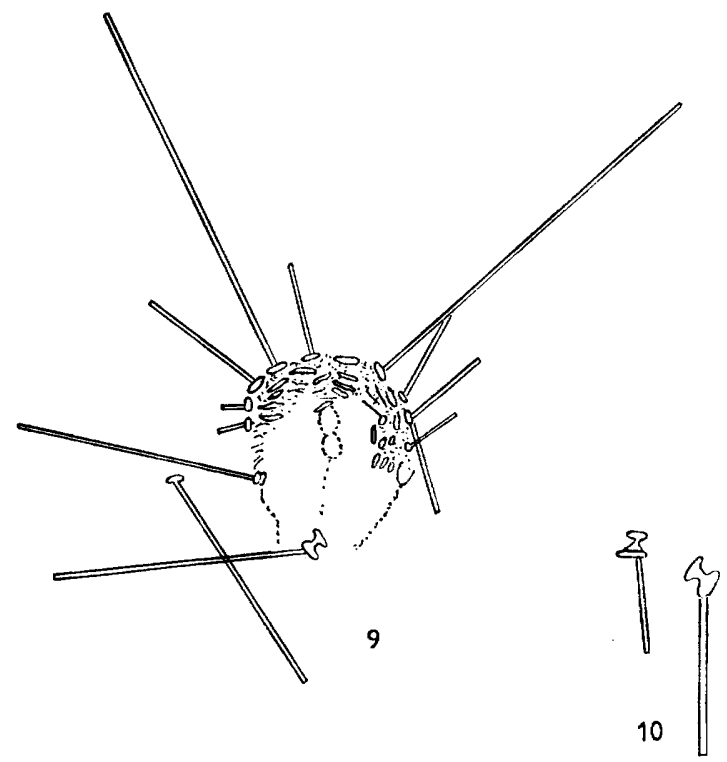

Fig. 9. Chrysosphaerella multispina, dried single cell, $\times 1000$.

Fig. 10. C. multispina, spines, $\times 1700$.

Chrysosphaerella multispina sp.nov. (Figs. 7-10; Pl. 6, figs. 44-50)

Diagnosis. Corpus coloniale. Unaquaque colonia cellulas continet viginti ad quadriginta. Chromatophoros profunde bilobata. Superficies cellulae spinis squamisque contecta. Unaquaque cellula fere quindecim spinas fert. Spinarum duae longae, tres vel plures mediae, breves multae. Ea pars spinae quae cellulae est coniuncta structuram fert fusiformem. Pars exterior spinae biceps, complanata. Squamae ovatae e quibus minores nullis signatae notis, maiores costis paucis et crassis, vel radiis rotae similibus vel forma reticulata.

Dimensiones. Cellula $10 \mu \times 15 \mu$, setae $35-40 \mu, 20-25 \mu, 5-10 \mu$, squamae 0.6-6 $\mu$.

English diagnosis. Colonial organism, each colony with 20-40 cells. Cells ovoid. Chromatophore deeply bilobed. Cell surface covered with spines and scales. Spines about 15 in number to each cell : two long spines, three or more medium spines, and many short spines. Spines have bobbin-like structure at the end attached to the 
cell. Outer end is two-pointed and flattened. Scales oval, smaller ones unsculptured, larger ones with few thickened ribs resembling spokes or in a reticulate pattern.

Occurrence. Found in a deep pit at type locality, Hverhóll, Skidadalur, near Dalvik. Apparently widespread in northern Iceland, other localities being Kleif, Arskogsströnd, near Akureyri; Ljosvatn, near Godafoss and Myvatn. The water was at $\mathrm{pH} 7 \cdot 0$.

Table 2. Features of Chrysosphaerella longispina, C. brevispina and C. multispina
C. longispina*
C. brevispina

\begin{tabular}{|c|c|c|c|}
\hline No. of spines & $\begin{array}{l}\text { Up to } 5 \text {, usually } \\
\mathbf{3}-\mathbf{4}\end{array}$ & 2-11 & About 15 \\
\hline Length of spines $(\mu)$ & $25-40$ & Up to 18 & $5-40$ \\
\hline Scale morphology & $\begin{array}{l}\text { Oval, thickened } \\
\text { inner ring with } \\
\text { spokes radiating } \\
\text { to margin }\end{array}$ & $\begin{array}{l}\text { Oval, inner ring near } \\
\text { margin, spokes } \\
\text { short }\end{array}$ & $\begin{array}{l}\text { Oval, smooth } \\
\text { margin, reticulate } \\
\text { in centre }\end{array}$ \\
\hline
\end{tabular}

Name derivation. The name 'multispina' refers to the numerous spines.

Comparison. The species of Chrysosphaerella all look rather similar in the light microscope so that identifications with this instrument must be carried out with great care. The electron microscope, however, reveals clear-cut differences. The main diagnostic features are summarized in Table 2 . In addition, two points may be added in comparison with $C$. brevispina. First, the cells of $C$. multispina are bigger, and secondly the shape of the bobbin is different (see Harris \& Bradley, 1958).

It is pointed out that the numerous medium and long spines of Chrysosphaerella multispina tend to be overlooked in the live organism. They are best seen in dried preparations in the light microscope, and it seems that they provide the most obvious characteristics. Nevertheless, it may be argued that variations in the number and length of bristles might occur at different stages of the development of the organism. This is considered unlikely since the various widely spread populations in Iceland all had similar numbers of spines.

\section{CONCLUSION}

It is clear that the three genera of Chrysophyceae studied are abundant in northern Iceland. However, the noticeably sparse populations found suggest that the optimum season is probably earlier than in July, and climatic conditions indicate that it is more likely to be in May. Some eleven different species of the genus Mallomonas were found over a comparatively small area in the space of a few weeks in July. Thus at the optimum season Iceland could provide numerous species and much information on the taxonomy of this genus. The position regarding the genera Synura an Chrysosphaerella is less certain. The former genus, though common, possesses relatively few species at present, three of these being found in Iceland, but only two being common. The single species of Chrysosphaerella was widespread.

In view of the geographical position of Iceland, it is interesting to note that the 
species of the three genera found are similar to those described from other parts of the world, and that the new species fit well with the existing scheme of classification.

The author would like to thank Professor T. M. Harris, F.R.S., and Mrs K. Harris, University of Reading, for valuable criticism and discussion, Mrs M. Moss, Miss M. McCulloch and Miss A. Dewar for technical assistance, and Professor M. M. Swann, F.R.S., for his interest and advice. The author is also grateful to the University of Edinburgh for providing a research grant for this work, thus enabling him to carry out light-microscope studies and collection in the course of the Edinburgh University Iceland Expedition, 1963. Mr Einar Petersen of Klief, Arskogsströnd, Akureyri, took a keen interest in the work and generously permitted the full use of his land by the expedition for collecting and camping. The translations of diagnoses into Latin were kindly carried out by Mr W. S. M. Nicoll, Department of Humanity, University of Edinburgh.

Field work was carried out with the permission of the Icelandic Government.

\section{REFERENCES}

Asmund, B. (1956). Electron microscope observations on Mallomonas species and remarks on their occurrence in Danish ponds. II. Bot. Tidsskr. 53, 75.

Asmund, B. (1959). Electron microscope observations on Mallomonas species and some remarks on their occurrence in Danish ponds and lakes. III. Dansk. bot. Ark. 18, 3.

Boureliy, P. (1951). Une nouvelle espèce de Chrysomonadines: Mallomonas doignonii. Bull. Soc. bot. Fr. 98, 196.

HARRIs, K. (1958). A study of Mallomonas insignis and Mallomonas akrokomos. J. gen. Microbiol. 19, 55 .

Harris, K. \& Bradley, D. E. (1957). An examination of the scales and bristles of Mallomonas in the electron microscope using carbon replicas. J. R. micr. Soc. 76, 37.

Harris, K. \& Bradrey, D. E. (1958). Some unusual Chrysophyceae studied in the electron microscope. J. gen. Microbiol. 18, 71.

Harris, K. \& Bradley, D. E. (1960). A taxonomic study of Mallomonas. J. gen. Microbiol. 22, 750.

Konshikov, A. A. (1941). On some new or little known flagellates. Arch. Protistenk. 95, 22.

Lauterborn, R. (1896). Diagnosen neuer Protozoen des Oberrheins. Zool. Anz. 19, 14.

Lauterborn, R. (1899). Protozoen Studien. IV. Teil. Flagellaten des Oberrheins. Z. wiss. Zool. 65, 369.

LUND, J. W. G. (1942). Contributions to our knowledge of British Chrysophyceae. New Phytol. 41, 274.

Petersen, J. B. \& Hansen, J. B. (1956). On the scales of some Synura species. Biol. Medd., Kbh. 23, 1.

Skuja, H. (1948). Taxonomie des Phytoplanktons einiger Seen in Uppland, Sweden. Symb. bot. upsaliens, $\mathbf{9}, \mathbf{3}$.

TAKahashi, E. (1963). Studies on genera Mallomonas, Synura and other plankton in fresh water with the electron microscope. IV. On two new species of Mallomonas found in ditches at Tsuruoka in the Northeast of Japan. Bull. Yamagata Univ. 4, 169.

Villeket, S. (1954). Deux nouvelles espèces de Chrysomonadines. Bull. Soc. bot. Fr. 101, 106. 

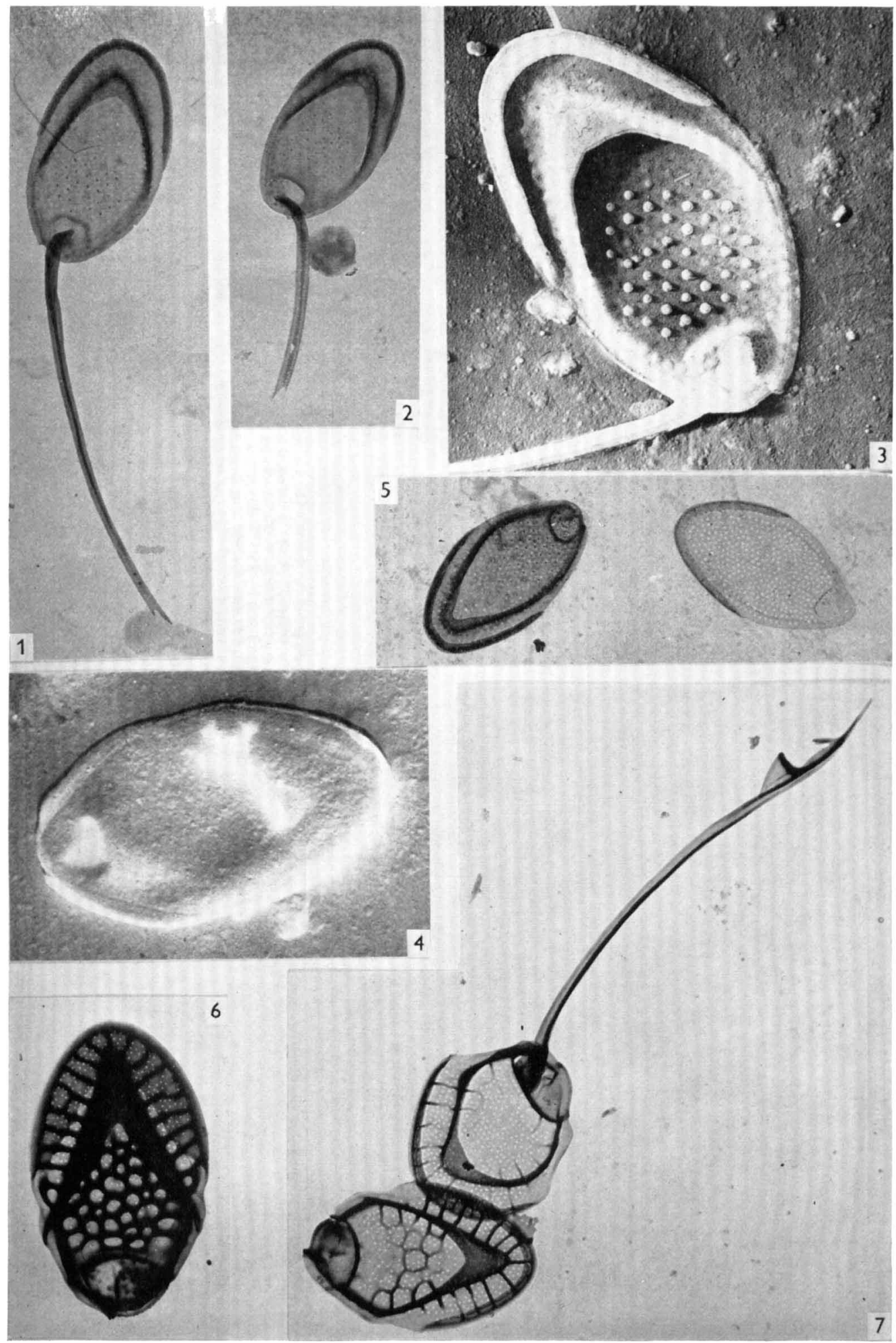
Journal of General Microbiology, Vol. 37, No. 3

Plate 2

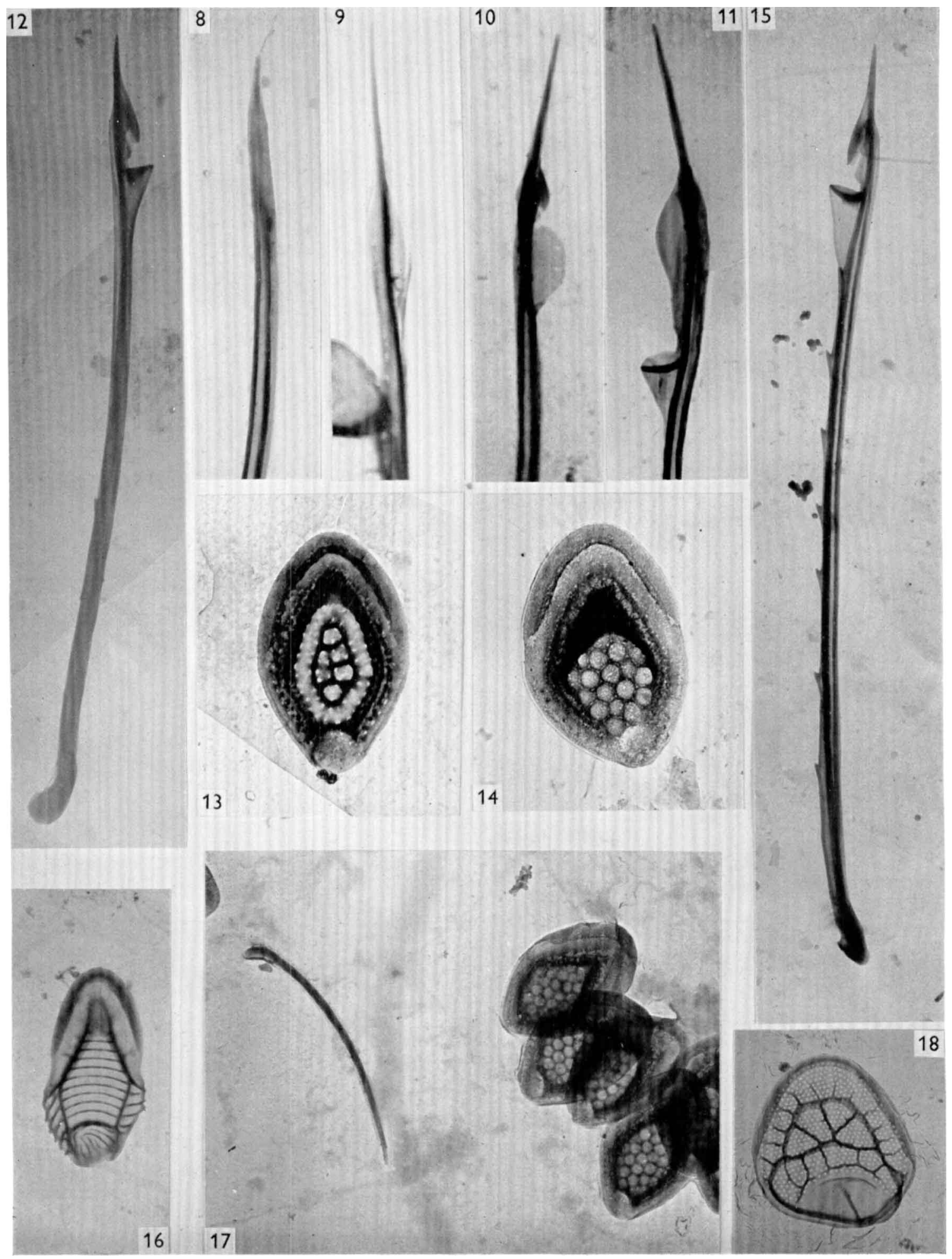

D. E. BRAILLEY 


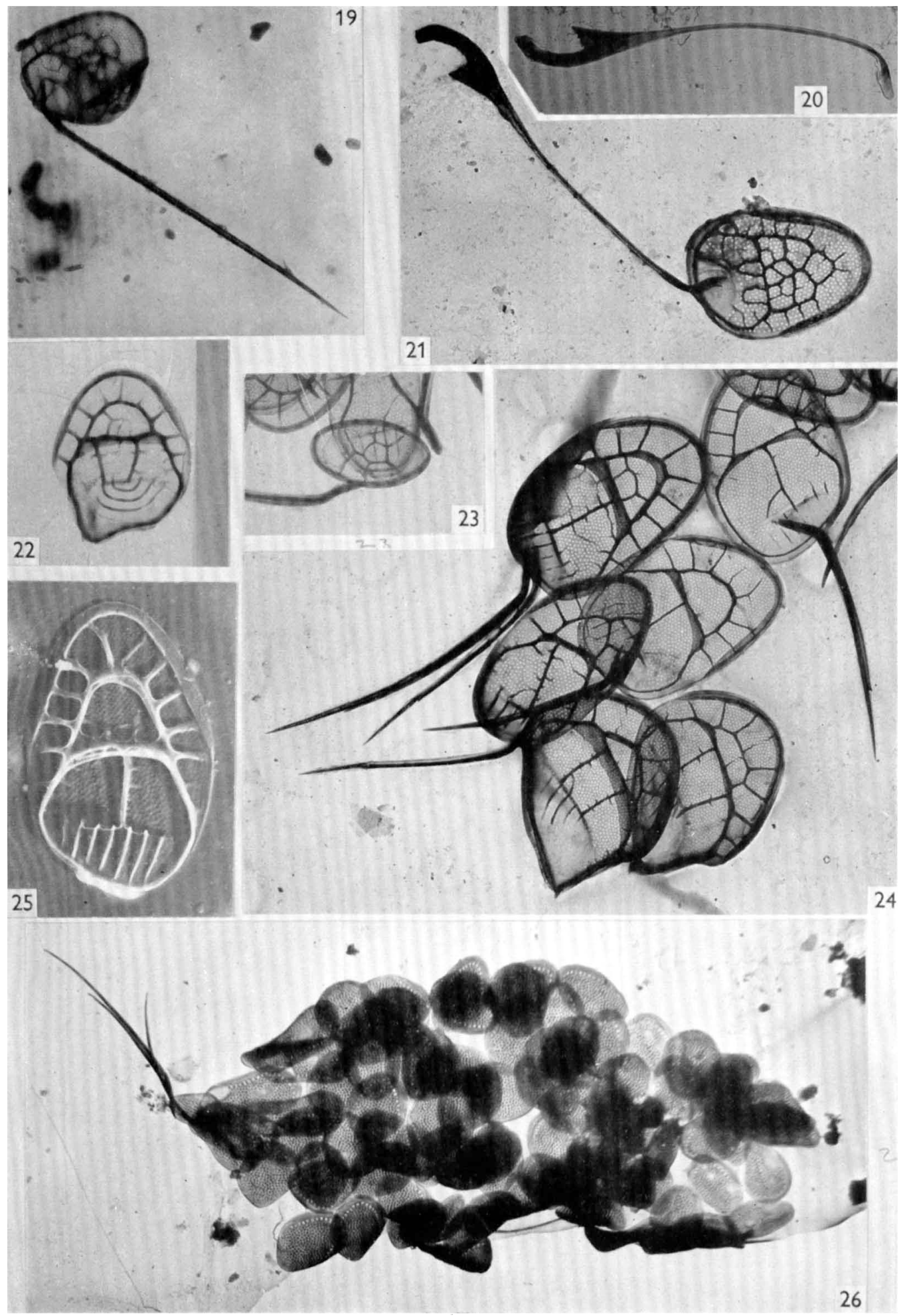

D. L. BRADLEY 
Journal of General Microbiology, Vol. 37, No. 3

Plate 4
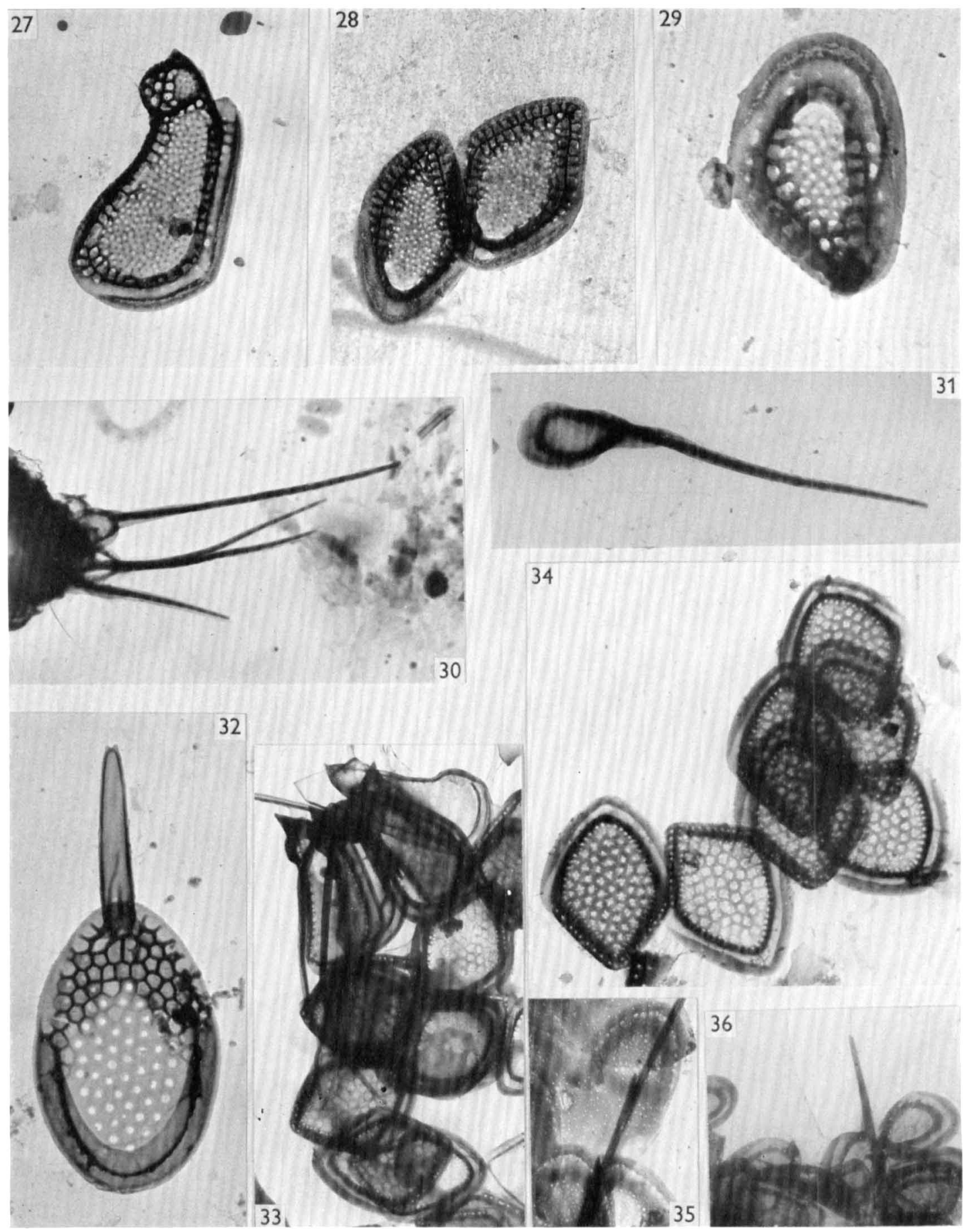

D. E. BRADLEY 
Journal of General Microbiology, Vol. 37, No. 3

Plate 5
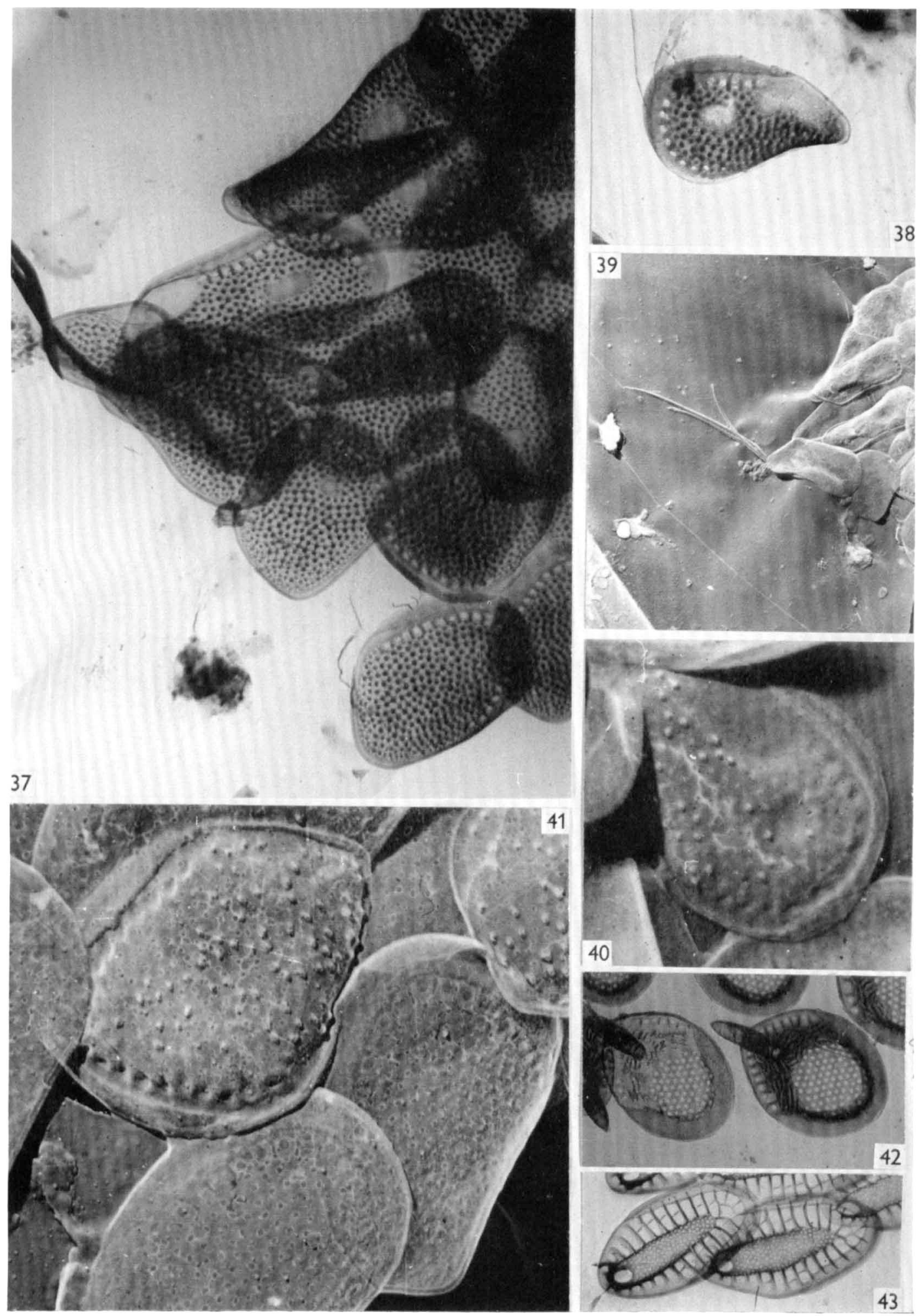

D. E. BRADLEY 
Journal of General Microbiology, Vol. 37, No. 3

Plate 6
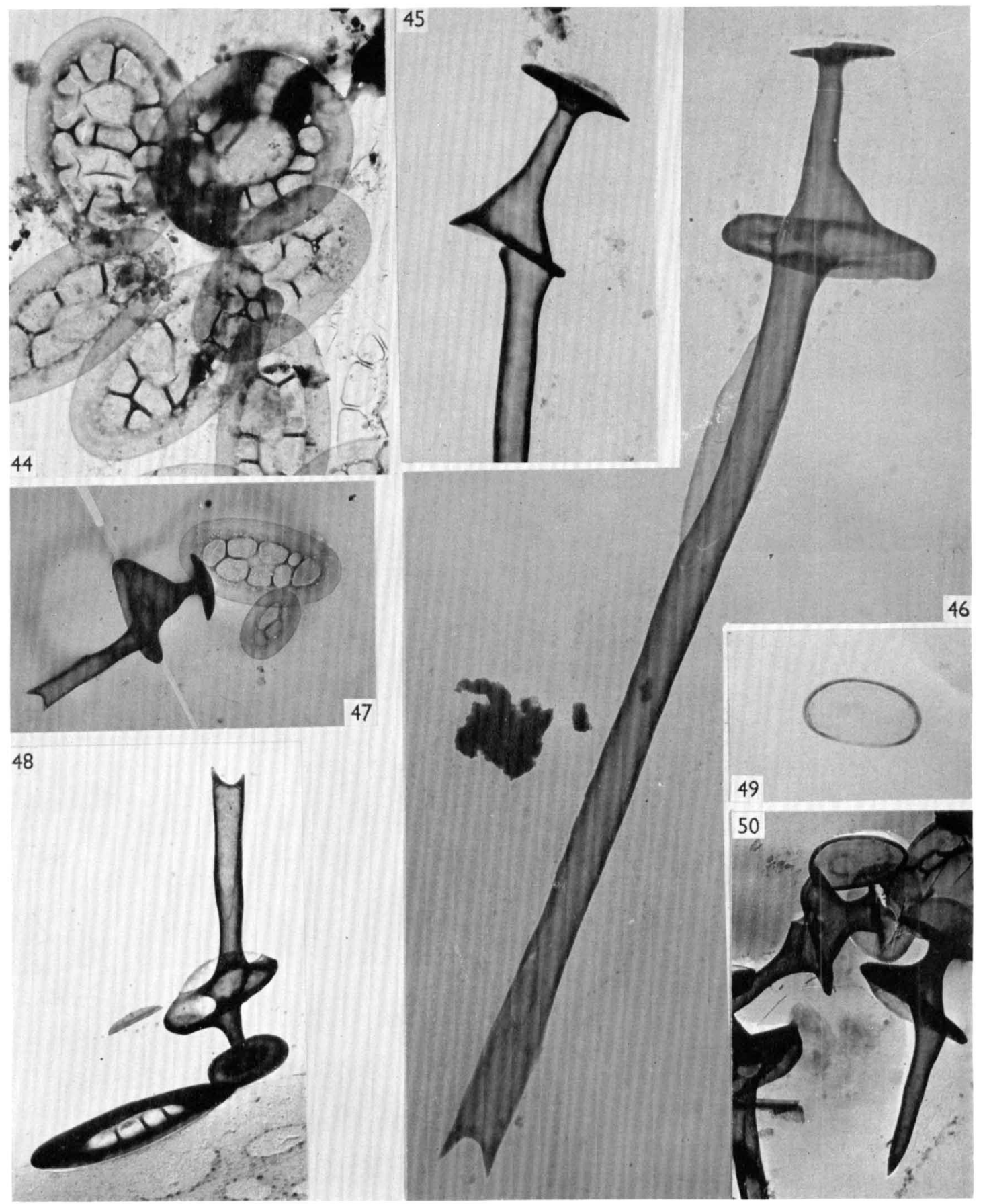

D. E. BRADLEY 


\section{EXPLANATION OF PLATES}

Plate 1

Fig. 1. Mallomonas calceolus, direct micrograph of scale and bristle, $\times 10,000$.

Fig. 2. $M$. calceolus, scale with short bristle, $\times 10,000$.

Fig. 3. $M$. calceolus, shadowed scale showing outer surface, $\times 25,000$.

Fig. 4. $M$. calceolus, shadowed carbon replica showing inner surface of scale, $\times 20,000$.

Fig. 5. $M$. calceolus, mature (left) and immature (right) scales, direct, $\times \mathbf{7 5 0 0}$.

Fig. 6. $M$. acaroides var. craquissima, direct micrograph of scale, $\times 6000$.

Fig. 7. $M$. acaroides var. galeata, scales and bristle, $\times 6000$.

\section{Plate 2}

Figs. 8-11. Mallomonas acaroides var. galeata, variations in bristle tip, $\times 12,000$.

Fig. 12. M. acaroides var. craquissima, bristle, $\times 6000$.

Fig. 13. Undescribed species from Másvatn, scale, $\times 15,000$.

Fig. 14. Undescribed species from Myvatn, scale, $\times 15,000$.

Fig. 15. $M$. acaroides var. craquissima, serrated helmet bristle, $\times 6000$.

Fig. 16. M. striata var. striatula, $\times 6000$.

Fig. 17. Undescribed species (?same as in Fig. 14) from Myvatn, bristle and scales, $\times 9000$.

Fig. 18. M. heterospina, scale from Mordruvellir, $\times 9000$.

\section{Plate 3}

Fig. 19. Mallomonas heterospina, scale and pointed bristle from Kleif, $\times 6000$.

Fig. 20. M. hetercspina, 'spanner' bristle, from Mordruvellir, $\times 7500$.

Fig. 21. $M$. heterospina, scale and 'spanner' bristle from Kleif, $\times 7500$.

Fig. 22. $M$. pugio, scale with abnormal dome, $\times 7500$.

Fig. 23. $M$. pugio, domeless scale, $\times 7500$.

Fig. 24. $M$. pugio, body scales and bristles, $\times 7500$.

Fig. 25. M. pugio, shadowed scale, $\times 9000$.

Fig. 26. M. maculata, direct micrograph of whole organısm, $\times \mathbf{2 8 0 0}$.

\section{Plate 4}

Fig. 27. Mallomonas (undescribed), from Skidadalur, anterior scale, $\times 12,000$.

Fig. 28. Mallomonas (undescribed), from Skidadalur, domeless body scales, $\times 12,000$.

Fig. 29. Mallomonas (undescribed), from Skidadalur, posterior scale, $\times 24,000$.

Fig. 30. $M$. clavus, posterior scale elongated into spike, $\times 8000$.

Fig. 31. M. clavus, posterior spikes, $\times 7500$.

Fig. 32. Synura spinosa forma spinosa, scale $\times 12,000$.

Fig. 33. M. akrokomos, scales and part of bristle, $\times 9000$.

Fig. 34. $M$. clavus, body scales, $\times 7500$.

Fig. 35. M. clavus, pointed anterior scales, $\times 7500$.

Fig. 36. $M$. clavus, posterior scales, $\times 7500$.

\section{Prate 5}

Fig. 37. Mallomonas maculata, anterior scales, $\times 8000$.

Fig. 38. M. maculata, posterior scale, $\times 8000$.

Fig. 39. M. maculata, shadowed replica of anterior end of cell, $\times 2800$.

Fig. 40. M. maculata, shadowed replica of posterior scale, $\times 14,000$.

Fig. 41. $M$. maculata, shadowed replica of body scales, $\times 14,000$.

Fig. 42. Synura echinulata, scales $\times 7500$.

Fig. 43. S. petersenii, scales, $\times 7500$.

\section{Plate 6}

Fig. 44. Chrysosphaerella multispina, scales, $\times 8000$.

Fig. 45. C. multispina, 'bobbin' at base of spine, $\times 8000$.

Fig. 46. C. multispina, entire spine, $\times 8000$.

Fig. 47. C. multispina, short spine and scales, $\times 6000$.

Fig. 48. C. multispina, short spine and scale in profile, $\times 7500$.

Fig. 49. C. multispina, small unsculptured scale, $\times 12,000$.

Fig. 50. C. multispina, short spine oriented to show flattened tip, $\times 8000$. 